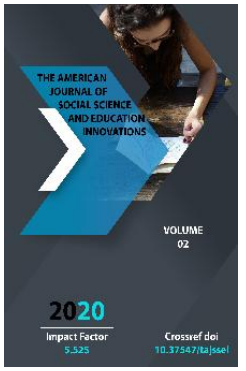

\title{
Hohler Is A Master Of Words And Language
}

\section{Hafiza Kuchkarova}

PhD Student, Department Of World Literature, National University, Uzbekistan

Journal Website: http://usajournalshub.c om/index,php/tajssei

Copyright: Original content from this work may be used under the terms of the creative commons attributes 4.0 licence.

\section{ABSTRACT}

This article discusses the literary skills of the famous Swiss writer Franz Hohler, his writing style, the topics he covers, the genres of his works, the originality of the plot and composition in his stories, the concept of portraiture in his work, the ability to use dialogues appropriately and effectively. The article analyzes some of the writer's stories.

\section{KEYWORDS}

Genre, story, plot, composition, portrait, dialogue.

\section{INTRODUCTION}

The first element of literature is language. Language is the main tool of literature, its events, along with facts, is its material. The word is the garment of all facts, all thoughts. But at the heart of every fact is social meaning, and at the heart of every meaning is the reason why this or that idea is and why not.

The second element of the literature is the subject. The theme is an idea that was created in the author's experience, demonstrated by life itself, but has not yet been fully embodied in the author's imagination, requiring the 
incarnation in images and inculcating a tendency to work in the author. There will also be topics that are considered "eternal". These are: death, love themes.

The third element of literature is the plot, that is, the interrelationships, contradictions, likes and dislikes of people, the relationship between people in general - the history, growth, formation of this or that character, type.

Literature goes into labor. This concept is a difficult type of labor. Thinking is harder than manual labor. After all, thinking is also a difficult type of labor. As our great writer Abdullah Qadiri said: "You need to know better, the pencil is not a o'qlog'i (a long smooth stick that spreads the dough) and the press is not a hoe market. Sentences from every word that comes to mind improperly are not considered a virtue of weaving. Let the word be molded, let the thought be the brick laid in it, let it lay the foundation for a new awning of life as many are baked from the potter's wheel! It takes a long time to say a word and make a sentence out of it. It is a great crime for a writer to understand only himself and others not. It is a misunderstanding that the original writer was trying to convey the point he wanted to make to everyone equally"[1].

\section{THE MAIN FINDINGS AND RESULTS}

The writer should be able to demonstrate their skills in the writing process. "Literature must have its own time and place in every age. Literature should be in close contact with life" [2]. It is necessary to understand a fact that has a deep, critical significance for writers, and that is: life is enriched by various, extraordinary events, and the reader is the direct creator of these events. Literature should be in very, very close contact with life.
The works of European literature of the following years are enriched with new tones, and the style of expression of European literature is enriched in new ways. It is distinguished by the bubble of expression, the richness of the image, the content, the variety of moods, and the fact that artistic methods are giving way to the artistic study of man. The protagonist is characterized by the fact that the processes in his imagination and experiences become the object of the image, the realization, the desire to understand it more fully.

Modern Swiss literature today has a place not only in European but also in world literature. Today, Swiss literature differs from the literature of other nations in that it is more weighty and meaningful than ever. At a glance, what issues the literature of this neutral country raises raises the interest of today's readers.

Franz Hohler, one of the great representatives of modern Swiss literature, is one of the writers who took a step into literature with his unique style. His writing style is commendable. Although writing style is an individual aspect of each author's ability. At the heart of these features is an objective indicator of the origin and growth of the author. The writer's ability to observe and study reality is commendable. He can literally be called an observant realist. He is known not only as a writer but also as a poet and children's writer in Switzerland and Germanspeaking countries, particularly Germany, Luxembourg and Liechtenstein. His works have been translated into 37 languages of the world, including Uzbek.

Franz Hohler's visit to Uzbekistan in April 2018 delighted fans of Uzbek literature. The presentation of his collection of short stories "Sayr sayqali" [3], translated into Uzbek, was attended by the author. While reading 
excerpts from his works in the author's own language at literary evenings across Uzbekistan, readers became aware that the author has his own style. Despite the fact that the stories included in the Uzbek collection are covered on a variety of topics, their consistency and the specific direction of the events in people's social life do not fail to attract our attention. After all, there is a fact that is profound and important for writers: life is enriched by diverse, extraordinary events, and the reader, who is well aware that he is the direct creator of these events, can enter the world of literature today. "Anyone who wants to be a good writer has to define their attitude to life. In order for him to take an active part in this life, he must study it actively. $"$ [4].

Described in Switzerland as the "Master of the Word," Hohler first emerges as a storyteller. While there was nothing unusual in his stories, he was able to instantly conquer the world of literature. With the stories of "52 Journeys", the writer immerses the reader in his own stories, as if the reader himself "follows" the writer, so eloquently that the charm of his stories lies in their simplicity. Stories take you on a journey without difficulty. "[5] His story "Chakalakzor" (thicket) begins as follows: "When we think of the endless thickets, for some reason we remember our crazy childhood". In the collection of short stories "Tosh" (Stone) he continues: "The art of painting is the heaviest of the arts. You only bring the word chakalakzor(thicket) to life in your imagination. This requires patience. The hardest thing in art is patience," he said. In a real sense, Holer is bringing beauty into our lives with his work. He and his work are an example for many young artists.

Despite his young age, Lucas Berfus, who already has a worthy place in the hearts of readers: "I thank you and what you have written for learning so much from you and what you have written. "[6] Let us focus on some of the issues that Franz Hohler faces as a writer in his work and how to deal with these challenges:

He is more interested in the question of the density of the story in the composition. Density is actually the amount of content on a page or section of text. Sometimes a few pages describe the event in such detail that the smallest details, not only the external actions that are barely noticeable, but also the internal-mental actions are listed. We observe that Hohler did not include secondary individuals in his stories. Even if positions are included, the author engages them in dialogues. Although dialogues may seem simple to read, they are one of the most difficult parts of prose. To do this, you need to know well the dialogues in life. The dialogue should be lively, not only to show the spiritual experience of a person, but also to reveal his character. Dialogue should never turn into nonsense, simple deception, should never replace the author's text. We often think that it would be interesting if the main character said the words of the author. But this is a delusion. No hero can be "trusted" to say what the author has to say. Also, what the protagonists have to say, the author should take on and not speak in a third party language.

Hohler's achievement is his use of living material. He seeks not only the most important and typical things, but also the most vital, most relevant facts and personalities that are necessary to express the idea of the work from reality. In addition to learning from life, of course, he also learned a great deal of artistic heritage. When a writer has a real attitude to creation, he has to work a lot that is unknown to anyone: observation, questioning, searching, meeting dozens of 
people, living among them, eating with them, knowing their lives, understanding their profession, mastering vocabulary, learning about debates, conflicts, getting into their inner world and emotions, and so on. He has a realistic attitude towards the protagonist in his works, does not weave an artificial environment, depicts it in relation to the living environment, works without forgetting that the protagonist has unique personal characteristics.

A writer's work is not limited to a writing desk. Before starting work on a fiction book, before writing the first page, there is usually a long and varied preparation process: facts are studied, people are interviewed, material is collected.

Language is rooted in the deep social foundations of life. How to hear this language? You need to be able to see it. It is the law for a writer to create a work by seeing what he is describing using his emotions.

How to work? You need to observe the environment, communicate with people, think, read and know.

When talking about the artistic skills of the writer, the following should be kept in mind: first, the writer must know life well, keep pace with the present, be truly modern, that is, be at the level of the advanced ideas of his time, and live in harmony with the people. Second, the writer must clearly see the purpose for which he intends to serve and subdue his work. He tries to make simple and clear sentences.

\section{CONCLUSION}

The life experience of a writer is not only what he saw, what he experienced, what happened in his life - it is also what he read in books and heard from other people's stories about what he saw and experienced. What the writer himself experienced, saw or met up close will be of the utmost importance in a work of art.

\section{REFERENCES}

1. Abdullah Qadiri. To our writers, Mushtum. 1926. №-17.

2. About artistic creation. Digest of articles. Tashkent: 1960

3. Hohler F. The walk is beautiful. Qochqorova H. Translation of hours. Tashkent: Akademnashr. 2018.

4. About artistic creation. Collection of articles. Tashkent: 1960. -p. 46.

5. Hans Ulrich Probst. Zurich.

6. Berfus L. Zurich, from a speech on September 20, 2005. 